\title{
Effectivity of Vertical Sub-Surface Downflow Constructed Wetland System with Varying Composition in Reducing Chromium and Color in Synthetic Textile Wastewater
}

\author{
M. Razick Masyyika and Devi N. Choesin
}

\begin{abstract}
Textile and leather tannery wastewater pollute water bodies with their content of chromium metal $(\mathrm{Cr})$ and synthetic dyes which are highly toxic. The use of constructed wetland systems is an approach to treat such wastewater before being discharged directly into the environment. This study was conducted to examine the effectiveness of vertical sub-surface downflow constructed wetlands with varying composition in decreasing $\mathrm{Cr}$ concentration and color thickness (value) in synthetic textile wastewater. Systems were varied by substrate composition and presence of the plant Leersia hexandra. Synthetic textile wastewater containing $\mathrm{K}_{2} \mathrm{Cr}_{2} \mathrm{O}_{7}$ and reactive dye were flowed downward into five systems: (1) soil-sandgravel substrate, without plants; (2) soil-sand-wood chips substrate, without plants; (3) soil-sand-gravel substrate, and L.hexandra plants; (4) soil-sand-wood chips substrate, and L. hexandra plants; and (5) a system without substrate or plants as control. Chromium concentration and color thickness were measured at 8, 16, 24, 32 and 40 hours after treatment. Measurements at 8 hours showed that systems no. $1,2,3$, and 4 decreased $\mathrm{Cr}$ concentration in effluent as much as $87,6 \% ; 79,1 \% ; 81,4 \%$; and $89,2 \%$ respectively. Meanwhile $\mathrm{Cr}$ concentration in the control system's effluent remained relatively constant. Systems no. 1, 2, 3, and 4 decolorized the effluent up to $94,6 \% ; 89,6 \% ; 93,4 \%$; and $86,0 \%$ respectively; meanwhile, color in the control system was unchanged. All four treatment systems could effectively reduce $\mathrm{Cr}$ concentration and color thickness in synthetic textile wastewater. However, results did not support the hypothesis that the presence of plants would significantly affect $\mathrm{Cr}$ removal, or that the addition of wood chips to substrate would enhance decolorization effects.
\end{abstract}

Keywords-Vertical sub-surface downflow constructed wetland, Leersia hexandra, textile wastewater, chromium, decolorization

\section{INTRODUCTION}

Chromium $(\mathrm{Cr})$ and reactive dye are used in the production of textile, dye, and tanned leather products. Chromium is known as a trace element in plant and animal metabolism and has two stable forms, i.e., the trivalent form and the hexavalent form, which is regulated tightly in its use [1].

Manuscript received 18 January 2016.

Authors are from the Biology program, School of Life Sciences and Technology, Institut Teknologi Bandung
Chromium is often used in chemical industries, for example, it is used for electroplating, leather tanning, and dye production. As waste, chromium is toxic to living organisms [2]. In Indonesia, the maximum allowable concentration $(\mathrm{mg} / \mathrm{L})$ of chromium as leather tanning waste is limited to 0,6 $\mathrm{mg} / \mathrm{L}[3]$.

Reactive dye is soluble in water and strongly binds to fabric fibers and leathers [4]' it produces a dense color in water [5]. Every year, a high amount of reactive dyes is produced, 10$15 \%$ of which is released back to the environment, i.e., water bodies, and most are carsinogenic [5]. If wastes containing chromium and reactive dyes are not controlled, they could lower the water quality, and thus must be treated properly as soon as possible. Use of a constructed wetland system is an alternative for processing wastewaters of textile and leather tanning factories. The system's effectivity is affected by physical, chemical, and biological factors [6].

The objective of this study was to assess the effectivity of constructed wetland systems in reducing chromium and color density in synthetic wastewater. The systems tested were varied by the presence of plants and by substrate composition.

\section{Methodology}

\section{A. Constructed wetland and synthetic wastewater}

Constructed wetland systems were built as vertical subsurface downflow systems (batch). Five systems were built in the form of glass aquariums with $0.8 \mathrm{~mm}$ glass thickness and dimensions of $20 \times 20 \times 50 \mathrm{~cm}^{3}$ with a valve at the bottom. Rubber buckets were made into wastewater containers, with holes at the bottom of each container to control the outlet water flow, the flow was kept stable between 0.41 and 0.5 $\mathrm{mL} / \mathrm{s}$. Leersia hexandra plants were used as chromium phytoaccumulator [1]. Plants were acclimated for one week before being integrated into the systems. Substrate was stratified in layers of similar weight and thickness, each layer weighed 4 $\mathrm{kg}$ or $10 \mathrm{~cm}$ in thickness. The five systems compared were (Figure 1): (1) a system with substrate composed of soil-sandgravel (SSG); (2) a system with substrate composed of soilsand-woodchips (SSW); (3) a system with substrate composed of soil-sand-gravel and planted with Leersia 
hexandra (SSG+L); (4) a system with substrate composed of soil-sand-woodchips and planted with $L$. hexandra $(\mathrm{SSW}+\mathrm{L})$; and (5) a control without any substrate or plants. Woodchips were used as adsorbent although they need a long retention time to take effect [7].

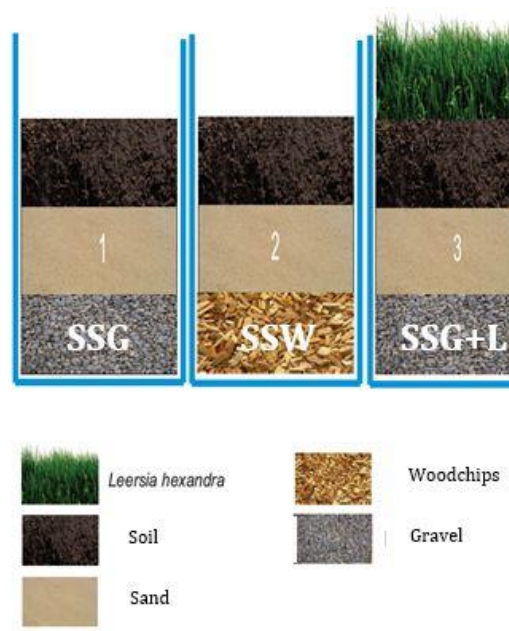

Fig. 1 Constructed wetland model

Synthetic wastewater was made of dissolved hot reactive dye (Procion H-E) with a concentration of $50 \mathrm{mg} / \mathrm{L}$ and $\mathrm{K}_{2} \mathrm{Cr}_{2} \mathrm{O}_{7}$ concentration of $20 \mathrm{mg} / \mathrm{L}$, with deionized water as solvent.

\section{B. Experiment}

Each system was run with three replications. Wastewater was trickled intermittently from above the systems through the holes at the bottom of the buckets. Physical conditions such as air temperature, water temperature, and substrate (soil) acidity were measured during the experimental run. Air temperature was measured using a sling psychrometer, water temperature using a DO-meter, and substrate acidity using a soil tester. The amount $100 \mathrm{~mL}$ of effluent was sampled through the valve using a beaker glass five times in 40 hours (sampled every 8 hours, at $8^{\text {th }}, 16^{\text {th }}, 24^{\text {th }}, 32^{\text {nd }}$, and $40^{\text {th }}$ hours). Dissolved oxygen (DO) measurement was conducted immediately after the effluent was sampled, followed by $\mathrm{pH}$ and conductivity measurements.

Substrate and plants were sampled at t $-5\left(40^{\text {th }}\right.$ hour $)$ using an auger, then mixed. Plant and substrate samples were dried at $75^{\circ} \mathrm{C}$ in an oven for 24 hours.

\section{Sample preparation and analysis}

Sample preparation is the first step before measuring metal content in samples using atomic absorption spectrophotometer (AAS). For effluent samples, $5 \mathrm{~mL}$ of $\mathrm{HNO}_{3} 65 \%$ were added to $50 \mathrm{~mL}$ samples each in a beaker glass. Each glass was closed using a watch glass and vapored until $20 \mathrm{~mL}$ of sample remains and the sample appears clear (if the sample is not clear enough, $5 \mathrm{~mL}$ of $\mathrm{HNO}_{3}$ could be added once). Condensed vapors on the watch glass was rinsed using aquadest and stored into the remaining sample until the volume reached $50 \mathrm{~mL}$. Samples were moved into a volumetric flask and homogenized. The homogenized samples were then filtered through filter papers and stored in labelled bottles.

Preparation of substrate samples was conducted by dissolving the samples into $50 \mathrm{~mL} \mathrm{HNO}_{3} 65 \%$ and heated at $60^{\circ} \mathrm{C}$ for two hours. The samples were filtered then stored in labelled bottles. For plant samples, $10 \mathrm{~mL} \mathrm{HNO}_{3} 65 \%$ were added to $0.5 \mathrm{gr}$ of dried plant samples and heated at $60^{\circ} \mathrm{C}$ for two hours, filtered afterwards, and stored in labelled bottles.

Metal content analysis was conducted using AAS. Meanwhile decolorization percentage was measured using the absorbance data of effluent samples. Absorbance data were measured at wavelength of $520 \mathrm{~nm}$ using an UV-VIS spectrophotometer. Data were then analyzed statistically using one-way ANOVA.

\section{RESUlts AND DISCUSSION}

\section{A. Reduction of chromium}

Measurements for $\mathrm{pH}$ and DO of sampled effluents from each system in 40 hours are presented in Figure 2. Average $\mathrm{pH}$ varied between 6.3 and 6.6; while DO levels decreased with time, with DO in systems 1 to 4 at 40 hours measuring $2.6 ; 1.6 ; 2.5$; and $0.9 \mathrm{mg} / \mathrm{L}$ respectively.

Chromium concentration of effluents measured between 2.17 and $5.0 \mathrm{mg} / \mathrm{L}$ at 40 hours, with the lowest chromium concentration recorded in system no. 4 (SSW+L) (Fig. 2). The graph shows the reduction of chromium in each system since the $8^{\text {th }}$ hour. Systems 1 to 4 reduced chromium concentrations as much as $87.6 \% ; 79.1 \% ; 81.4 \%$ and $89.2 \%$ respectively. However, at the $16^{\text {th }}, 24^{\text {th }}, 32^{\text {nd }}$, and $40^{\text {th }}$ hours of observation, the systems did not exhibit significant changes in the concentration of chromium in effluents.
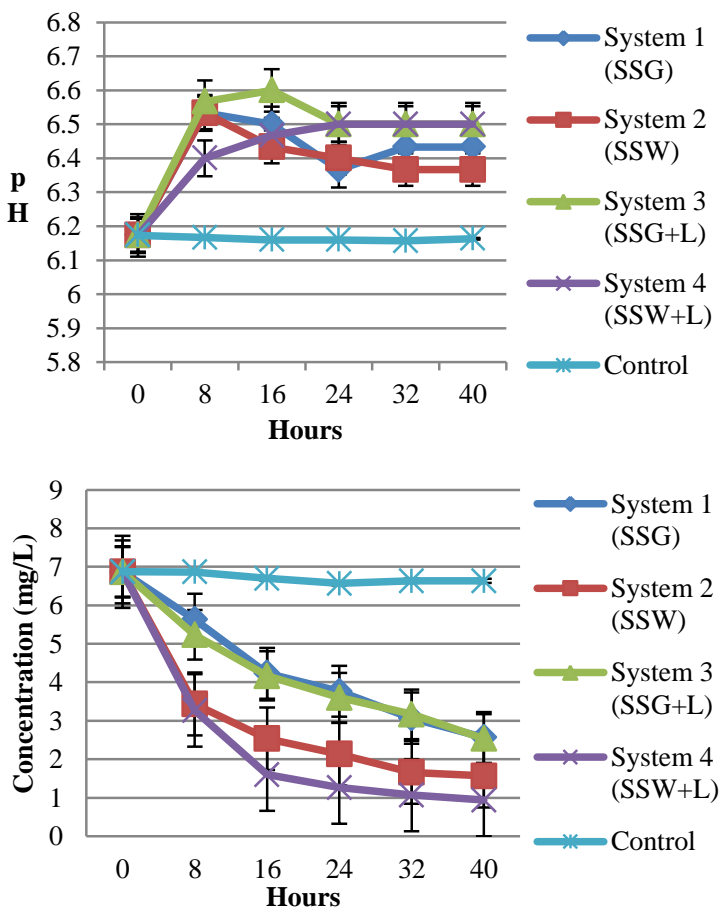

Fig. $2 \mathrm{pH}$ and DO conditions of each system sampled at $8^{\text {th }}, 16^{\text {th }}, 24^{\text {th }}, 32^{\text {th }}$, and $40^{\text {th }}$ hours 


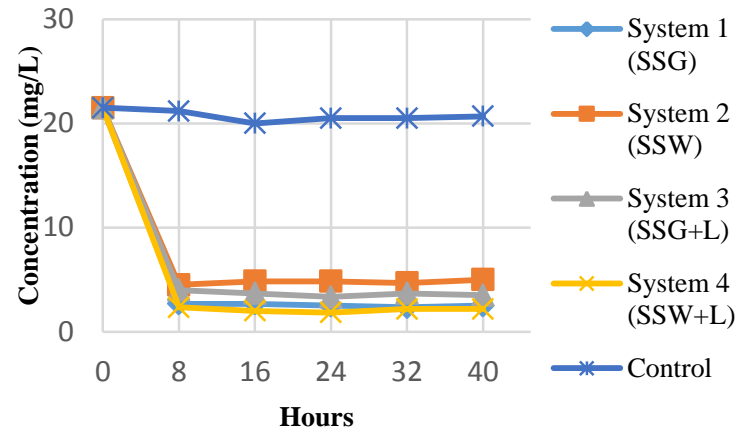

Fig. 3 Chromium concentration of effuents at $8^{\text {th }}, 16^{\text {th }}, 24^{\text {th }}, 32^{\text {nd }}$, and $40^{\text {th }}$ hours

Chromium reduction in effluents could be caused by reduction mechanisms by other metals, electron transfer, or adsorption. In the system containing soil and sand, $\mathrm{Cr}(\mathrm{VI})$ could be reduced by $\mathrm{Fe}(\mathrm{II})$ and organic matters to produce $\mathrm{Cr}(\mathrm{III})$ which is immobile and not soluble in water. Reduction caused by $\mathrm{Fe}$ (II) occurs at neutral $\mathrm{pH}$ and hipoxic condition [8], meanwhile reduction rate induced by organic matter is proportional to the amount of $\mathrm{Cr}(\mathrm{VI})$ and organic matters [8]. $\mathrm{Cr}(\mathrm{VI})$ could be mobilised in anaerobic/hipoxic condition [8]. In the observed systems, $\mathrm{Cr}(\mathrm{VI})$ could be reduced into $\mathrm{Cr}(\mathrm{III})$ by $\mathrm{Fe}(\mathrm{II})$ and organic matters, while $\mathrm{pH}$ and $\mathrm{DO}$ conditions support the reduction mechanism by Fe(II) [8].

Chromium reduction in effluent is supported by the substrate's ability to reduce chromium mobility. Consecutively, systems 1 to 4 could contain 510; 488; 435; and $450 \mathrm{mg} / \mathrm{kg}$ of chromium (Fig. 4). Chromium level in substrate increased because $\mathrm{Cr}(\mathrm{VI})$ and $\mathrm{Cr}(\mathrm{III})$ could be well absorbed by substrate particles. The difference in chromium levels could be related to the different capabilities of the different substrate types. Sand could adsorp $\mathrm{Cr}(\mathrm{VI})$ in a $\mathrm{pH}$ range between 5 and 7,5 because in that range the sand's surface is mostly positively charged. Moreover $\mathrm{Cr}(\mathrm{VI})$ reduction mechanism by $\mathrm{Fe}(\mathrm{II})$ in soil occurred easily in neutral $\mathrm{pH}$, the mobile and soluble $\mathrm{Cr}(\mathrm{VI})$ could be reduced into $\mathrm{Cr}(\mathrm{III})$ which is immobile and not soluble in water in neutral $\mathrm{pH}$. $\mathrm{Cr}(\mathrm{III})$ could be absorbed and bind in soil with the help of iron oxide, clay, and sand [8]. Adsorption of $\mathrm{Cr}(\mathrm{III})$ rapidly occurred in soil when $\mathrm{pH}$ level increased [9].

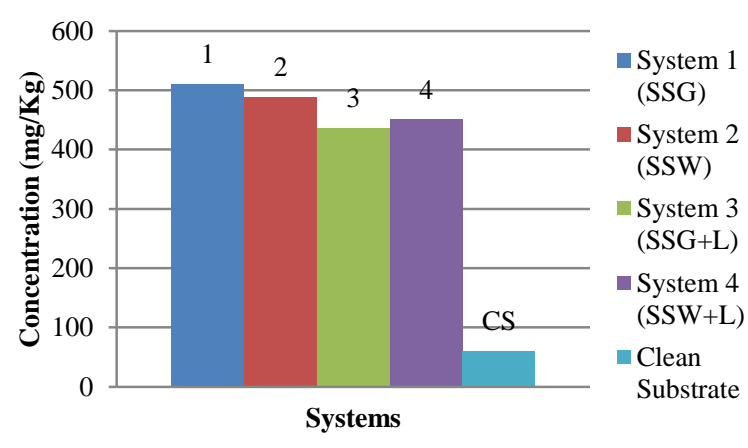

Fig. 4 Chromium concentration in substrate at $40^{\text {th }}$ hour.
Other than substrate, Leersia hexandra had a role in absorbing and storing chromium. In 40 hours $L$. hexandra in systems 3 and 4 could absorb $186 \pm 23,1 \mathrm{mg} / \mathrm{kg}$ and $200 \pm 40$ $\mathrm{mg} / \mathrm{kg}$ into their roots, but not their leaves or stems (possibly stored in a tiny amount in leaves and stems).

Compared to the result of Zhang's experiment in 2007 [1] (in which he reported storage of $6978 \mathrm{mg} / \mathrm{kg}$ chromium in $L$. hexandra roots), the amount of chromium absorbed in our results is lower, because of the batch system (without further addition of synthetic wastewater) and the applied retention time. Substrate's role in capturing/binding chromium ions could lower the probability of chromium absorption by $L$. hexandra's roots; other than that, the low amount of absorbed chromium could be caused by metal competitors absorbed through the same pathway of transport, for example Fe(III). $\mathrm{Fe}$ (III) is a reductor in the reduction process of $\mathrm{Cr}(\mathrm{VI})$ into $\mathrm{Cr}(\mathrm{III})$; if reduction rate of $\mathrm{Cr}(\mathrm{VI})$ increases, then the production rate of $\mathrm{Fe}(\mathrm{III})$ as a competitor metal for $\mathrm{Cr}$ (III) increases as well, this process could hinder $\mathrm{Cr}$ (III) uptake by plants, and thus result in the accumulation of $\mathrm{Cr}$ (III) in substrate [10].

\section{TABLE 1: CHROMIUM CONCENTRATION IN Leersia hexandra}

\begin{tabular}{c|ccc}
\hline System & \multicolumn{3}{|c}{ Chromium content } \\
& Root & Stems & Leaves \\
\hline System 3 (SSG+L) & $186,7 \pm 23,1 \mathrm{mg} / \mathrm{kg}$ & N/A & N/A \\
System 4 (SSW+L) & $200 \pm 40 \mathrm{mg} / \mathrm{kg}$ & N/A & N/A \\
\hline N/A $=$ Not detected & & & \\
\hline
\end{tabular}

\section{B. Decolorization}

Decolorization in effluent was apparent since the $8^{\text {th }}$ hours. Then measurements remained relatively unchanged at the $16^{\text {th }}, 24^{\text {th }}, 32^{\text {nd }}$ and $40^{\text {th }}$ hour observations. Decolorization percentages in systems 1 to 4 were consecutively $94.6 \%$; $89.6 \%$; $93.4 \%$; and $86.0 \%$, while there was no change in the control system. In comparison, system 1 (SSG) and system 3 $(\mathrm{SSG}+\mathrm{L})$ produced better decolorization results than system 3 (SSW) and system $4(\mathrm{SSW}+\mathrm{L})$. This was due to the woodchips giving a yellowish color to the effluent and thus raising the absorbance measurement when assessed using spectrophotometer at the same wavelength. Decolorization occurred because adsorption by soil particles, organic matter, and sand particles went well [11], but not when the water reached the woodchips layer. 


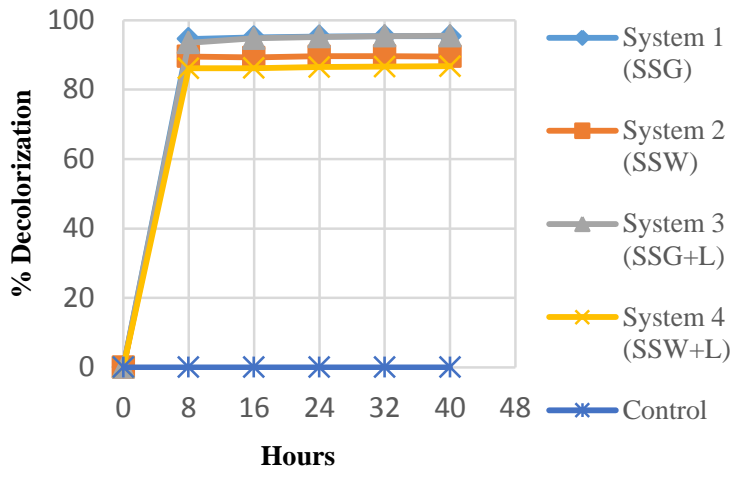

Fig. 5 Decolorization percentages sampled at $8^{\text {th }}, 16^{\text {th }}, 24^{\text {th }}, 32^{\text {nd }}$ and $40^{\text {th }}$ hours.

Other than adsorption, degradation by proteins secreted by living organisms could affect the level of decolorization, because when substrates were sampled and re-dissolved into water, no color was produced; this indicates that not only adsorption occurred in the systems (because adsorbed materials could be released back into the environment and create the same effect as before) [11].

\section{CONCLUSION}

Constructed wetland systems in this study effectively lowered chromium concentration in wastewater effluents. In 8 hours, systems $1,2,3,4$, varied by substrate and presence of plants, could lower chromium concentration as much as $87.6 \%$; 79.1\%; $81.4 \%$; and $89.2 \%$ respectively. Although the results showed no significant differences among systems, substrate had an important role in holding chromiun and preventing it from polluting the outer system. In this system Leersia hexandra as accumulator did not have much effect in the short term. This could be caused by the metal competitors (Fe(III)) that hindered the uptake of $\mathrm{Cr}(\mathrm{III})$ by roots.

System 1, 2, 3, and 4 lowered the color density of wastewater as much as $94.6 \% ; 89.6 \%$; $93.4 \%$, and $86.0 \%$ respectively, while the control system did not have any effect in decolorizing effluents. Based on decolorization percentage, woodchips were not effective in reducing color density of density, because woodchips produced a yellowish color to the effluents. Adsorption and degradation activities in the systems are expected to play an important role in decolorizing effluents.

\section{REFERENCES}

[1] Zhang, X., Liu, J., Huang, H., Chen, J., Zhu, Y., dan Wang, D, "Chromium accumulation by the hyperaccumulator plant Leersia hexandra Swartz" in Chemosphere, 2006, Vol. 67, 1138-1143

[2] Wu, S., Chen, B., Sun, Y., Ren, B., Zhang, X., danWang, Y., "Chromium resistance of Dandelion (Tarazacum platypecidum Diels.) and Bermuda grass (Cynodon dactylon [Linn.] Pers.) is enhanced by Arbuscular Mycorrhiza in $\mathrm{Cr}(\mathrm{VI})$-contaminated soils" in Environmental Toxicology and Chemistry, 2014, Vol. 33, No. 9, 21052113. http://dx.doi.org/10.1002/etc.2661

[3] Keputusan Menteri Negara Lingkungan Hidup. 1996. KEP51/MENLH/10/1995 tentang Baku Mutu Limbah Cair Bagi Kegiatan Indstri.
[4] Hao, O.J., Kim, H., Chiang, P., "Decolorization of Wastewater. Critical Reviews in Environmental Science and Technology", 2010, 30:4, 449505. http://dx.doi.org/10.1080/10643380091184237

[5] Geethakarthi, A. dan Phanikumar, B.R., "Adsorption of reactive dyes from aqueous solutions by tannery sludge developed activated carbon: Kinetic and equilibrium studies" in International Journal Environment Science Technology, 2011, 8(3), 561-570. http://dx.doi.org/10.1007/BF03326242

[6] Bulc, T.G. dan Ojstrsek, A., "The use of constructed wetland for dyerich textile wastewater treatment" in Journal of Hazardous Materials, 2007, 155, 76-82. http://dx.doi.org/10.1016/j.jhazmat.2007.11.068

[7] Robinson, T., McMullan, G., Marchant, R., dan Nigam,P., "Remediation of dyes in textile effluent: a critical review on current treatment technologies with a proposed alternative" in Bioresource Technology, 2001, 77, 247-255. http://dx.doi.org/10.1016/S0960-8524(00)00080-8

[8] Independent Environmental Technical Evaluation Group. Chromium(VI) Handbook. CRC Press, 2005, New York, U.S.A.

[9] Choppala, G., Bolan, N., Mallavarapu, M., dan Chen, Z. 2010, "Sorption and mobility of chromium species in a range of soil types" presented at 19th World Congress of Soil Science, Soil Solutions for Changing World, Brisbane, Australia, 1-6 August 2010.

[10] Liu, J., Duan, C., Zhang, X., Zhu, Y., dan Lu, X., "Potential of Leersia hexandra Swartz for phytoextraction of Cr from soil" in Journal of Hazard Material, 2011, 1-3, 85-91. http://dx.doi.org/10.1016/j.jhazmat.2011.01.066

[11] Bhatt, M., Patel, M., Bhavin, R., Novotny, C., Molitoris, H.P., dan Sasek, V. "Biological decolorization of the synthetic dye RBBR in contaminated soil" in World Journal of Microbiology \& Biotechnology, 2000, Vol. 16, 195-198. http://dx.doi.org/10.1023/A:1008937503675 